\title{
Expression of a Single-Chain Variable-Fragment Antibody Against a Fusarium virguliforme Toxin Peptide Enhances Tolerance to Sudden Death Syndrome in Transgenic Soybean Plants
}

\author{
Hargeet K. Brar and Madan K. Bhattacharyya \\ Department of Agronomy and Interdepartmental Genetics Graduate Major Program, lowa State University, Ames 50011-1010, \\ U.S.A.
}

Submitted 20 December 2011. Accepted 24 February 2012.

\begin{abstract}
Plants do not produce antibodies. However, plants can correctly assemble functional antibody molecules encoded by mammalian antibody genes. Many plant diseases are caused by pathogen toxins. One such disease is the soybean sudden death syndrome (SDS). SDS is a serious disease caused by the fungal pathogen Fusarium virguliforme. The pathogen, however, has never been isolated from diseased foliar tissues. Thus, one or more toxins produced by the pathogen have been considered to cause foliar SDS. One of these possible toxins, FvTox1, was recently identified. We investigated whether expression of anti-FvTox1 single-chain variable-fragment ( $\mathrm{ScFv}$ ) antibody in transgenic soybean can confer resistance to foliar SDS. We have created two scFv antibody genes, AntiFvTox1-1 and Anti-FvTox1-2, encoding anti-FvTox1 scFv antibodies from RNAs of a hybridoma cell line that expresses mouse monoclonal anti-FvTox1 $7 \mathrm{E8}$ antibody. Both anti-FvTox1 scFv antibodies interacted with an antigenic site of FvTox1 that binds to mouse monoclonal antiFvTox1 7E8 antibody. Binding of FvTox1 by the antiFvTox1 scFv antibodies, expressed in either Escherichia coli or transgenic soybean roots, was initially verified on nitrocellulose membranes. Expression of anti-FvTox1-1 in stable transgenic soybean plants resulted in enhanced foliar SDS resistance compared with that in nontransgenic control plants. Our results suggest that i) FvTox1 is an important pathogenicity factor for foliar SDS development and ii) expression of $\mathrm{ScFv}$ antibodies against pathogen toxins could be a suitable biotechnology approach for protecting crop plants from toxin-induced diseases.
\end{abstract}

A major distinction between plants and animals is the ability of animals but not plants to produce antibodies against foreign antigens, including those of pathogenic microorganisms. However, transgenic plants can assemble mammalian antibodies correctly (Hiatt et al. 1989). In early studies, genes encoding heavy and light chains of the antibody molecules were either expressed independently in individual transgenic plants and then assembled in the hybrids or co-expressed in the same

Corresponding author: M. K. Bhattacharyya; E-mail: mbhattac@iastate.edu; Telephone: +1.515.294.2505; Fax +1.515.294.3163.

* The $e$-Xtra logo stands for "electronic extra" and indicates that six supplementary figures are published online. transgenic plant to obtain the assembled antibody molecules (De Neve et al. 1993; Hiatt et al. 1989). However, due to the complexity in cloning the entire antibody molecules and, most importantly, differences in post-translational modifications between plants and mammals, this initial technology of plant antibody production did not become a method of choice. Expression of only the variable regions of the antibody molecule involved in antigen binding was attempted and became successful (Bird et al. 1988). We can now create antibody genes encoding i) fragment antigen-binding (Fab) antibodies consisting of both variable heavy $(\mathrm{VH})$ and variable light (VL) chains, ii) single-domain antibody expressing only the heavy chain regions, and iii) single-chain variable-fragment ( $\mathrm{scFv}$ ) antibody expressing only the variable regions of one heavy and one light chain (Supplementary Fig. S1). These smaller antibody molecules suffer less from correct folding and post translation modification problems in plants. It is also easier to target small antibody molecules to any subcellular compartments and extracellular matrix.

$\mathrm{scFv}$ antibodies have been successfully expressed in foreign hosts, including plants and bacteria (Better et al. 1988; Chaudhary et al. 1990; Galeffi et al. 2002; Huston et al. 1988; Yuan et al. 2000). In synthetic scFv antibody genes, both $\mathrm{VH}$ and VL chain fragments are joined by a polylinker (Bird et al. 1988). Addition of the KDEL sequence to the C-terminus enhances retention of the $\mathrm{scFv}$ molecules in endoplasmic reticulum, stabilization, and accumulation of the antibody molecules in plant cytosol (De Jaeger et al. 1999; Schouten et al. 1997).

Expression of a Fusarium cell-surface-specific scFv antibody fused to antifungal peptides in Arabidopsis thaliana conferred high levels of resistance against Fusarium oxysporum f. sp. matthiolae (Peschen et al. 2004). In Brassica napus, expression of a $\mathrm{scFv}$ against a mycelial antigen protected the transgenic plants from the stem rot disease caused by Sclerotinia sclerotiorum (Yajima et al. 2010). Transgenic wheat expressing an antifungal-scFv antibody fused to an antifungal peptide was shown to have increased tolerance to Fusarium head blight (Li et al. 2008). scFv antibodies have also been applied to reduce incidence of viral diseases in plants (Galeffi et al. 2002, 2005; Safarnejad et al. 2009; Tavladoraki et al. 1993) and phytoplasma (Le Gall et al. 1998).

A scFv has been shown to bind a mycotoxin, deoxynivalenol, when expressed in Escherichia coli (Choi et al. 2004). Similarly, an E. coli-expressed $\mathrm{scFv}$ against the cassiicolin toxin reduced necrotic lesion formation, when applied as droplets on the abaxial surface of the detached leaves of rubber tree 
(Sunderasan et al. 2009). A scFv antibody expressed in transgenic Arabidopsis plants bound to zearalenone toxin in enzymelinked immunosorbent assay (Yuan et al. 2000). However, the $\mathrm{scFv}$ antibodies have not been shown to bind in planta to pathogen toxins in stable transgenic plants.

In the United States, the sudden death syndrome (SDS) is a serious, emerging disease in soybean. The estimated annual crop losses from SDS are valued over \$300 million (Wrather and Koenning 2006). SDS resistance is encoded by more than 14 quantitative trait loci (QTL) (Kazi et al. 2008). SDS is caused by a soilborne fungus, $F$. virguliforme, previously known as F. solani f. sp. glycines (Rupe 1989). The pathogen has never been isolated from diseased foliar tissues. Toxins released by the pathogen in the infected roots have been considered to produce foliar SDS. We have recently isolated a toxin, FvTox1. It is a $13.5-\mathrm{kDa}$ acidic protein encoded by a single gene. Expressed FvTox1 protein causes foliar SDS-like symptoms in soybean (Brar et al. 2011).

We have used a hybridoma cell line expressing a mouse monoclonal anti-FvTox1 7E8 antibody to create two antiFvToxl antibody genes (Eswarakumar et al. 1997). Both genes, when expressed in E. coli and Agrobacterium rhizogenesinduced transformed soybean roots, produced anti-FvTox $1 \mathrm{scFv}$ antibodies that bind to FvTox1. Expression of anti-FvTox1-1 antibody significantly reduced the development of foliar SDS in stable transgenic soybean plants compared with the nontransgenic control. The results presented here not only establish, for the first time, that a plant antibody can reduce a toxin-induced plant disease but also that FvTox1 is a major pathogenicity factor for foliar SDS development in soybean. This biotechnology approach should be applicable to fighting other plant diseases that are induced by pathogen toxins.

\section{RESULTS}

\section{Two anti-FvTox 1 antibody genes encode} anti-FvTox1 antibodies.

The cDNAs generated from a hybridoma cell line expressing anti-FvTox1 7E8 monoclonal antibody (Brar et al. 2011) were used to polymerase chain reaction (PCR) amplify $\mathrm{VH}$ and VL antibody fragments: i) fragment 8-1 (468 bp), specific to the VH region, and ii) fragments 4-2 (399 bp) and 6-1 (270 bp), specific to the VL region. Each of the three DNA fragments showed high similarity to previously cloned antibody molecules (Supplementary Fig. S2). Two scFv antibody genes, anti-FvTox1-1 (8-1/4-2; accession number JF440965) and antiFvTox1-2 (8-1/6-1; accession number JF440966) were synthe- sized by joining the $\mathrm{VH}$ fragment to individual VL fragments with a flexible polylinker, $\left(\mathrm{Gly}_{4} \mathrm{Ser}\right)_{3}$.

Search of the Abysis database resulted in identification of three complementarity determining regions (CDR) in both $\mathrm{VH}$ chain 8-1 and VL chain 4-2 but only two in VL chain 6-1 (Supplementary Fig. S3). Cysteine residues were conserved at positions $\mathrm{H} 22$ and $\mathrm{H} 92$ in $\mathrm{VH}$ chain 8-1, only at position L88 in VL chain 4-2, and not conserved in VL chain 6-1. AntiFvTox1-1 and anti-FvTox1-2, expressed in E. coli, were slightly larger than expected because 37 amino acid residues, including an epitope, were added to the recombinant proteins from the expression vector (Supplementary Fig. S4).

\section{E. coli-expressed anti-FvTox1 scFv antibodies bind to FvTox1.}

The E. coli-expressed antibody proteins were evaluated for their binding abilities to FvTox1. Protein preparations from i) F. virguliforme culture filtrates containing FvTox1 and ii) a baculovirus-infected Sf21 insect cell line expressing FvTox1 were analyzed for interactions of anti-FvTox $1 \mathrm{scFv}$ antibodies to FvTox1. Anti-FvTox1-1 carrying three CDR sequences in both VH and VL chains bound to FvTox 1 strongly, whereas anti-FvTox 1-2 carrying two CDR in the VL reacted poorly to FvTox1 (Fig. 1).

\section{anti-FvTox1 scFv antibodies interacted specifically to the antigenic site of FvTox1.}

A DNA molecule encoding the KDEL (Lys-Asp-Glu-Leu) signal peptide for endoplasmic reticulum retention was fused to the $3^{\prime}$ ends of the anti-FvToxl-1 and anti-FvToxl-2 genes cloned in the binary vector pISUAgron5 (N. N. Narayanan and M. K. Bhattacharyya, unpublished). A. rhizogenes carrying individual anti-FvToxl genes in pISUAgron5 was used to generate transformed hairy roots. Expression of anti-FvToxl antibody genes in the transformed roots was confirmed by reverse-transcriptase (RT)-PCR and Western blot analyses (Supplementary Fig. S5). Both recombinant anti-FvTox1 scFv antibody proteins extracted from transgenic roots bound to FvTox1 (Supplementary Fig. S6).

To determine whether anti-FvTox $1 \mathrm{scFv}$ antibodies interacted with the same FvTox1 antigenic site recognized by the mouse anti-FvTox1 7E8 monoclonal antibody, truncated FvTox1 molecules were expressed in E. coli. Western blot analysis of the truncated FvTox1forms suggested that the antiFvTox1 7E8 monoclonal antibody recognized an epitope located in a region between amino acids 74 and 120 (Fig. 2). Both anti-FvTox1-1 and anti-FvTox1-2 scFv antibodies also bound
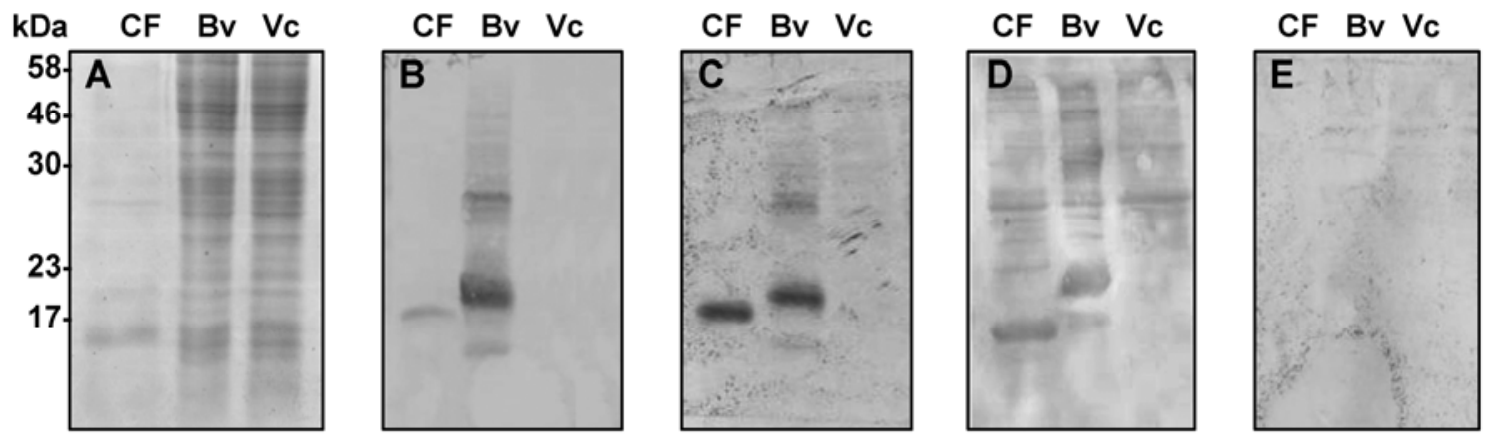

Fig. 1. Escherichia coli-expressed anti-FvTox1 single-chain variable-fragment (scFv) proteins bound to FvTox1. A, A protein gel (sodium dodecyl sulfate polyacrylamide gel electrophoresis) that has been stained with Coomassie Blue. B, FvTox1 was detected with mouse anti-FvTox1 7E8 monoclonal antibody; C, E. coli-expressed anti-FvTox1-1 was used as primary antibody; D, E. coli-expressed anti-FvTox1-2 was used as primary antibody; and E, E. coliexpressed GmPUB1 protein (30 kDa) served as negative control for primary antibodies. CF, Fusarium virguliforme culture filtrates; Bv, recombinant FvTox1 protein expressed in baculovirus-infected Sf21 insect cell line; Vc, protein preparation from Sf21 insect cell line infected with baculovirus carrying empty vector. E. coli-expressed $\mathrm{scFv}$ antibodies were tagged with Xpress epitope. Binding of E. coli-expressed anti-FvTox1 scFv antibodies to FvTox1 was detected using anti-Xpress antibody. 
to this region, suggesting that, most likely, anti-FvTox $1 \mathrm{scFv}$ antibodies retained the FvTox1-binding specificities of the antiFvTox1 7E8 monoclonal antibody (Fig. 2).

\section{anti-FvTox1-1 scFv antibody reduced \\ foliar SDS development.}

To determine the utility of the anti-FvTox 1 scFv antibody, the soybean 'Williams 82' was transformed with anti-FvToxl-1 carrying the $\mathrm{C}$-terminal KDEL signal peptide. The $\mathrm{T}_{1}$ progenies of a transformant $\left(\mathrm{T}_{0}\right)$ were analyzed for tolerance to FvTox1. Following $F$. virguliforme infection, a significant reduction in the extent of foliar symptom development was observed among most of the progenies compared with the nontransgenic control plants (Fig. 3). The average disease score for transgenic plants was significantly lower than that of the control plants (Fig. 3E). The average root length, stem length, and fresh weight were significantly higher in transgenic plants compared with that in nontransgenic control plants (Fig. 3F).

We investigated whether the transgenic plants were more tolerant to FvTox 1 than the nontransgenic control plants. SDS symptom development was monitored following feeding of transgenic and nontransgenic soybean plants with $F$. virguliforme culture filtrates containing FvTox1. Transgenic plants expressing anti-FvTox 1-1 showed enhanced tolerance to FvTox 1 compared with the nontransgenic control plants (Fig. 4A to E). Higher chlorophyll contents and lower foliar SDS disease scores were recorded for the transgenic plants compared with the nontransgenic control plants (Fig. 4F).

We then determined whether enhanced tolerance of transgenic progenies to FvTox 1 was due to expression of the anti-FvTox1-1 scFv antibody from a specific anti-FvToxl-1 transgene copy. Anti-FvTox1-1 scFv antibody accumulated in FvTox1-tolerant progenies but not in the FvTox1-sensitive progeny (Fig. 4G). Southern blot analysis revealed that enhanced FvTox1 tolerance was associated with the integration of an anti-FvToxl-1 transgene copy (Fig. 4H).

\section{anti-FvTox1-1 scFv antibody accumulated mostly in the cytoplasm.}

The subcellular locations of the accumulated anti-FvTox1-1 $\mathrm{scFv}$ antibody were determined by conducting transmission electron microscopy. KDEL is an ER retention signal and involved in retrieving proteins into ER through a KDEL-receptor mediated pathway (Capitani and Sallese 2009). As expected, anti-FvTox1-1 was localized mostly to cytoplasm (Fig. 5A). However, anti-FvTox 1-1 was localized to a smaller extent to the chloroplasts (Fig. 5B).

\section{DISCUSSION}

F. virguliforme releases at least one known proteinaceous toxin into the soybean roots $(\mathrm{H}$. K. Brar and $\mathrm{M}$. K. Bhattacharyya, unpublished). The toxin presumably travels through the vascular tissues to the aerial green tissues, where it causes foliar SDS symptoms (Brar et al. 2011; Li et al. 1999). This proteinaceous toxin, FvTox1, is encoded by a single gene (Brar et al. 2011). Here, we have shown the possible application of an anti-FvTox $1 \mathrm{scFv}$ antibody in reducing the phytotoxic effect of FvTox1 in stable transgenic soybean plants.

A hybridoma cell line producing the mouse monoclonal anti-FvTox $17 \mathrm{E} 8$ antibody was used to isolate the VH and VL regions of the antibody molecule. The isolated antibody fragments showed high similarities to the previously characterized variable fragments of other antibody molecules. Two cysteine residues, at positions $\mathrm{H} 22$ and H92 (Kabat et al. 1991), were conserved in $\mathrm{VH}$ chain 8-1. The cysteine residues of the
VL chains 4-2 and 6-1 were not completely conserved. Disulfide bonds between cysteine residues play an important role in correct folding and stabilization of immunoglobin structures. However, scFv antibodies lacking the conserved cysteine residues in VL fragments have been shown to retain their functionality (Proba et al. 1997, 1998). VH fragments have been shown to play a major role in antigen-binding activities because of the large diversity offered by its highly variable CDR3 region (Xu and Davis 2000). $\mathrm{VH}$ regions alone have been shown to act as functional antibodies in several studies (Bouaziz et al. 2009; Jobling et al. 2003; Rajabi-Memari et al. 2006). Both anti-FvTox 1-1 and anti-FvTox 1-2 bound to FvTox 1 on nitrocellulose membrane although neither carries conserved cysteine residues in their VL fragments. Most likely, the $\mathrm{VH}$ (8-1) fragment of the anti-FvTox1-2 scFv antibody containing a truncated VL (6-1) fragment is capable of binding to FvTox 1.

Foliar SDS causes most of the damage to the soybean crop. Light is essential for foliar SDS development (Brar et al. 2011; Ji et al. 2006). FvTox 1 has been localized to chloroplasts (Brar et al. 2011). Most likely, interruption of photosynthesis by

A
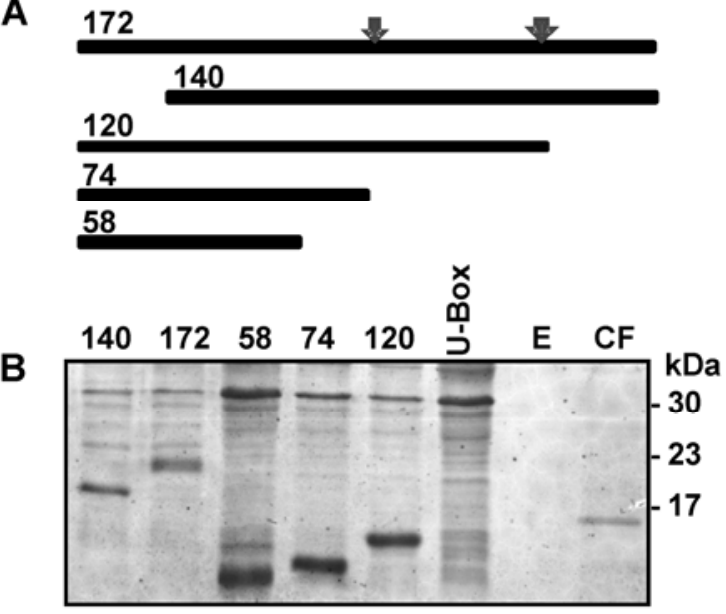

C

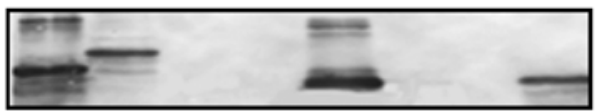

D

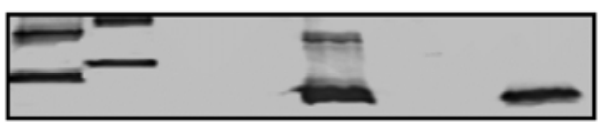

E

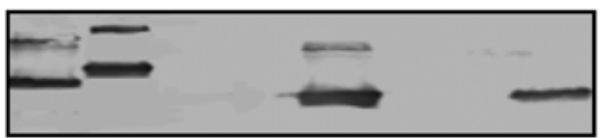

Fig. 2. Anti-FvTox1 single-chain variable-fragment $(\mathrm{scFv})$ antibodies retained the antigen-binding specificity of the mouse anti-FvTox1 7E8 monoclonal antibody. A, Diagram depicted the truncated forms of FvTox1. Region between the two arrows (based on results shown below in $\mathrm{C}$ ) contains the antigenic site bound by the mice monoclonal anti-FvTox1 7E8 antibody. B, Coomassie Blue stained gel of proteins expressed in Escherichia coli. Western blot analysis of the $E$. coli-expressed proteins using $\mathbf{C}$, monoclonal antiFvTox1 7E8 antibody or proteins extracted from D, Agrobacterium rhizogenes-induced transformed roots carrying anti-FvTox 1-1 gene with $K D E L$-tag fused to its $3^{\prime}$ end; or E, A. rhizogenes-induced transformed roots carrying anti-FvToxl-2 gene with KDEL-tag fused to its $3^{\prime}$ end. Lanes: 140, mature-FvTox $1_{(33-172 a a)} ; 172$, Pro-FvTox $1_{(1-172 a)} ; 58,58$ amino acids (aa) long pro-FvTox 1 protein truncated at the C-terminus; 74, 74 aa long pro-FvTox 1 protein truncated at the C-terminus; 120, 120 aa long pro-FvTox1 protein truncated at the $\mathrm{C}$ terminus; U-Box, an E. coliexpressed soybean U-Box protein; E, empty lane; CF, Fusarium virguliforme culture filtrate. 
FvTox1 leads to foliar SDS development in soybean. Through immuno-gold electron microscopy, we have shown that antiFvTox1-1 antibody accumulated mostly in cytoplasm and, to some extent, in chloroplasts of the transgenic soybean plants. Reduced symptom development and accumulation of the antibody mostly in cytoplasm indicated that anti-FvTox1-1 most likely bound to FvTox1 during FvTox1's entrance into chloroplasts through the cytoplasm. Our results showed that, although KDEL was added at the $C$ terminus of the antibody, it was targeted to chloroplasts from the ER. Many plastid proteins have been shown to contain ER-targeting signal peptides but not with any known signal peptides for chloroplast localization (Kleffmann et al. 2004). A novel protein transport pathway from ER to chloroplasts through Golgi has been proposed (Radhamony and Theg 2006). Chloroplast localization of antiFvTox1-1 (Fig. 5B) suggests that such a protein transport pathway may be involved in importing the $\mathrm{scFv}$ antibodies into chloroplasts from the ER.

anti-FvTox1-1 scFv antibody enhances the tolerance of leaves to FvTox 1 in the transgenic soybean plants compared with the nontransgenic controls (Figs. 3 and 4). Our study of stable transgenic soybean plants carrying the anti-FvToxl-1 antibody gene thus established that i) FvTox 1 is a major pathogenicity factor for foliar SDS development and ii) expression of a plant antibody against FvTox 1 can be suitable to reduce the foliar SDS in soybean. The transgenic plants did not show any de- tectible abnormality and set seed normally. Thus, this study sets the stage for engineering soybean for targeted expression of anti-FvTox 1 under the regulation of a leaf- and root-specific promoter to complement the SDS resistance encoded by a large number of QTL. Thus, the synthetic anti-FvToxl-1 gene created here should facilitate breeding soybean lines with enhanced SDS resistance.

\section{MATERIALS AND METHODS}

\section{Synthesis and cloning of anti-FvToxl antibody genes.}

Total RNAs were extracted from the anti-FvTox 1 7E8 hybridoma cell line (Brar et al. 2011) using Trizol reagent (Invitrogen, Carlsbad, CA, U.S.A.). RT-PCR was conducted using universal degenerated primers (Table 1) and amplified $\mathrm{VH}$ chain (VH 8-1, primers Deg CH1 and DegVH1) and VL chain (VL 4-2, primers DegCk1 and DegVk1, and VL 6-1, primers DegCk1 and DegVk4) fragments (Eswarakumar et al. 1997). A PCR thermal cycling $\left(94^{\circ} \mathrm{C}\right.$ for $2 \mathrm{~min}$ and $72^{\circ} \mathrm{C}$ for $4 \mathrm{~min}$, repeated seven times) was used to join the $\mathrm{VH}$ chain $(\mathrm{VH} 8-1)$ individually with the VL chains (VL 4-4 and VL 6-1) using a DNA sequence encoding an amino acid linker, $\left(\mathrm{Gly}_{4} \mathrm{Ser}\right)_{3}$, to obtain the synthetic antibody genes anti-FvToxl-1 and antiFvTox1-2. The synthetic genes were generated and were cloned into $E$. coli expression vector pRSET (Invitrogen) as XhoI and HindIII fragments.
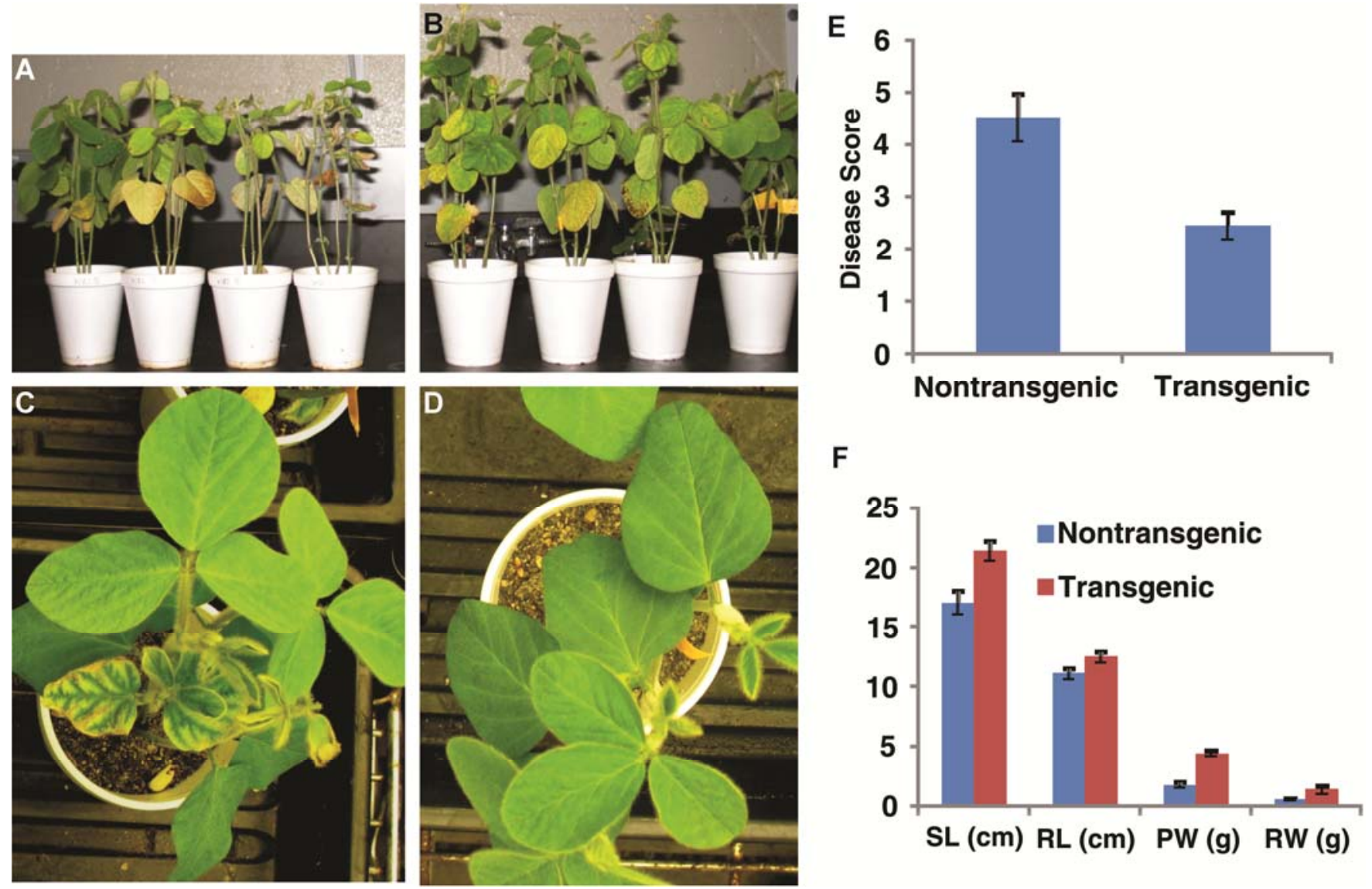

Fig. 3. Reduced foliar sudden death syndrome (SDS) development in transgenic plants following Fusarium virguliforme infection. A, Nontransgenic 'Williams 82' plants showed foliar SDS symptoms and retarded growth compared with the $\mathrm{T}_{1}$ progenies of $\mathbf{B}$, a transformant that showed reduced foliar SDS symptom development 5 weeks following infection of germinating seed with $F$. virguliforme. C, Nontransgenic Williams 82 plant showing susceptible foliar SDS symptoms in young trifoliates 5 weeks following infection with $F$. virguliforme. D, A transgenic plant carrying anti-FvTox1-1 antibody gene showed foliar SDS resistance trifoliates 5 weeks following infection with $F$. virguliforme. E, Reduced foliar SDS symptom development in transgenic plants compared with the nontransgenic control plants in A and B. F, Enhanced growth rates of transgenic plants carrying anti-FvTox1-1 compared with the nontransgenic control plants 5 weeks following infection with $F$. virguliforme. SL, shoot length; RL, root length; PW, average fresh weight of the entire plant; RW, average fresh root weight. 
Expression of anti-FvTox1 scFv antibodies.

E. coli BL21(DE3) pLysS cells were transformed with antiFvToxl-1 and anti-FvToxl-2 genes in pRSET plasmid and grown overnight at $30^{\circ} \mathrm{C}$ in $2 \mathrm{ml}$ of super optimal broth media containing ampicillin $(50 \mu \mathrm{g} / \mathrm{ml})$ and chloramphenicol (35 $\mu \mathrm{g} / \mathrm{ml})$. On the following day, the culture was diluted to an optical density at $600 \mathrm{~nm}\left(\mathrm{OD}_{600}\right)$ of 0.1 and incubated at $30^{\circ} \mathrm{C}$ until the culture reached an $\mathrm{OD}_{600}$ of 0.4 to 0.6 . Isopropyl-thio-galactopyranoside was added to a final concentration of $1 \mathrm{mM}$ and cells were allowed to grow for another $5 \mathrm{~h}$. The cells were pelleted and dissolved in $20 \mathrm{mM}$ phosphate buffer at $\mathrm{pH} 7$ and frozen in liquid nitrogen. Cells were frozen and thawed four times, then centrifuged at $14,000 \times g$ for $10 \mathrm{~min}$ at $4^{\circ} \mathrm{C}$. The supernatant was mixed with $2 \times$ sodium dodecyl sulfate loading dye $(125$ $\mathrm{mM}$ Tris- $\mathrm{HCl}$ [pH 6.8], $4 \% \mathrm{wt} / \mathrm{vol}$ sodium dodecyl sulfate, $20 \%$ [vol/vol] glycerol, $2 \%$ [vol/vol] $\beta$-mercaptoethanol, and $0.001 \%$ [wt/vol] bromophenol blue) and separated on a denaturing polyacrylamide gel electrophoresis (PAGE) gel for Western blot analysis. After blocking the nitrocellulose membrane with 5\% dry milk powder solution in $1 \times$ phosphate-buffered saline (PBS) at $\mathrm{pH} 7.5$, the mouse anti-Xpress antibody (Invitrogen) and then goat anti-mouse secondary antibody conjugated to alkaline phosphate (Bio-Rad Laboratories, Hercules, CA, U.S.A.) were added to the membrane. The binding of secondary antibody to anti-Xpress tag antibody was detected using the AP Conjugate Substrate Kit (Bio-Rad Laboratories).

\section{Binding of $E$. coli-expressed anti-FvTox1 scFv antibodies to FvTox1.}

FvTox 1 cloned in the pFastBac1 vector was expressed in the Sf21 insect cell line (Invitrogen) (Brar et al. 2011). The blots containing FvTox1 were hybridized to water-soluble E. coli proteins containing anti-FvTox $1 \mathrm{scFv}$ antibodies in $1 \times \mathrm{PBS}$ $(\mathrm{pH} 7.5)$ and then incubated with anti-Xpress antibody (Invitrogen). The goat anti-mouse antibody conjugated to AP (BioRad Laboratories) was used as the secondary antibody. West-
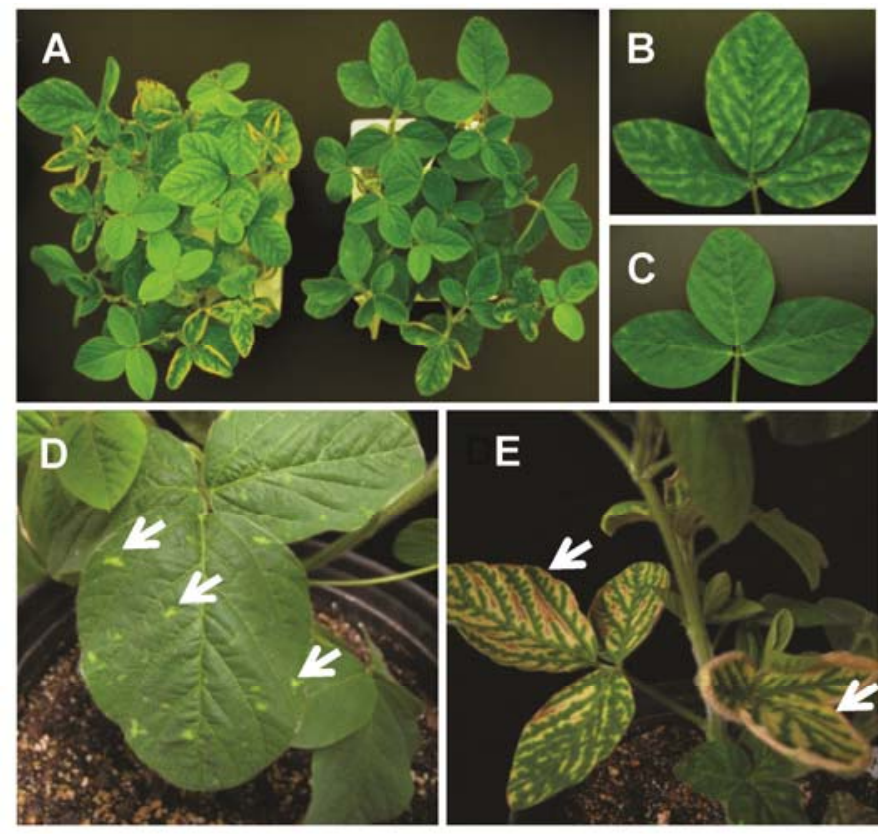

G

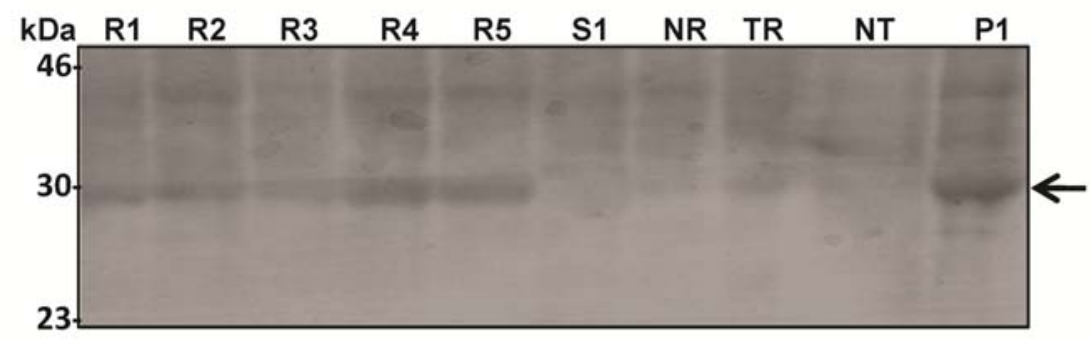

$\mathbf{F}$

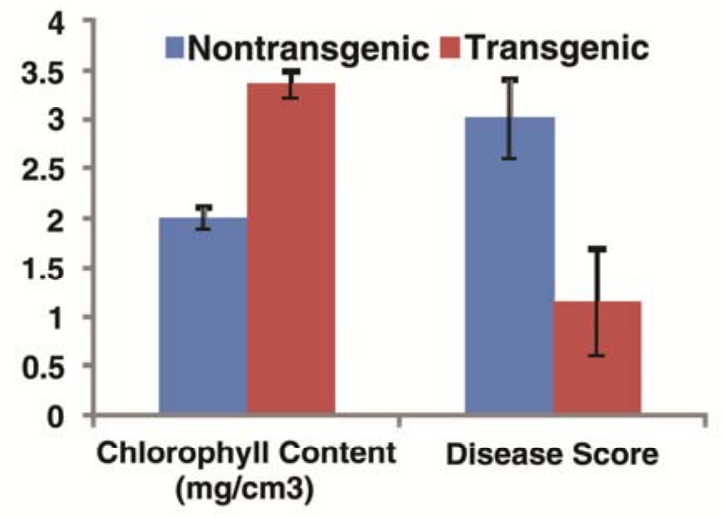

H

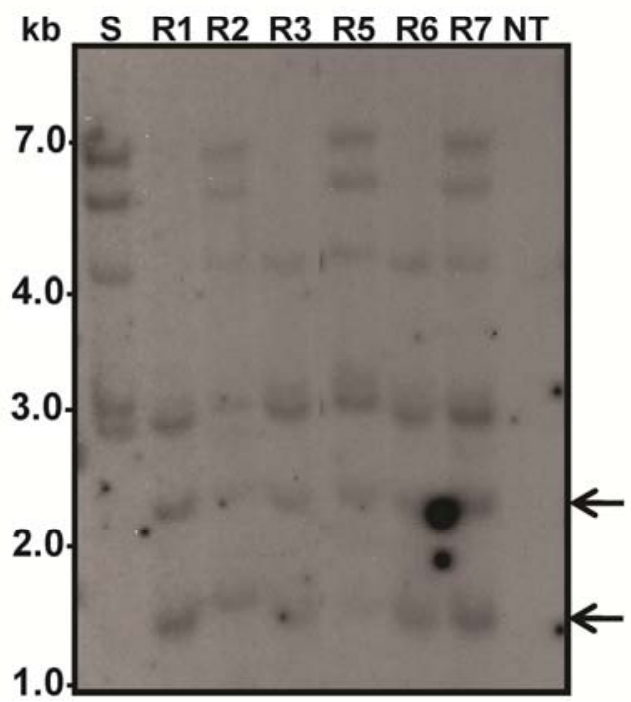

Fig. 4. $T_{1}$ progenies of a stable transgenic soybean line carrying anti-FvToxl-1 showed reduced foliar sudden death syndrome (SDS) development. A, Foliar SDS symptoms in nontransgenic (left) and transgenic (right) plants 2 weeks following feeding cell-free Fusarium virguliforme culture filtrates. B, Close-up picture of a diseased leaf of a nontransgenic plant and $\mathbf{C}$, close-up photo of a leaf of a transgenic plant 2 weeks following feeding cell-free $F$. virguliforme culture filtrates. D, Chlorotic foci developed in a leaf of a transgenic plant 4 weeks following feeding F. virguliforme culture filtrate. E, Severe foliar SDS development in leaves of a nontransgenic plant 4 weeks following feeding $F$. virguliforme culture filtrate. Plants shown in D and $\mathrm{E}$ were from a stem cut assay, planted in soil 2 weeks following feeding cell-free $F$. virguliforme culture filtrates. F, Quantification of foliar SDS symptoms. Chlorophyll content (mg/ $\mathrm{cm}^{3}$ ) and disease score were determined for the nontransgenic and transgenic soybean plants 2 weeks following feeding cell-free $F$. virguliforme culture filtrates. G, Western blot showing expression levels of anti-FvTox1-1 single-chain variable-fragment (scFv) antibody (arrow) among $\mathrm{T}_{1}$ progenies. R1-R5, SDSresistant progenies; S1, SDS-susceptible progeny; NR, nontransgenic soybean root; TR, transgenic soybean root; NT, nontransgenic soybean leaf; P1, a $\mathrm{T}_{1}$ progeny of the transgenic plant that was not evaluated for tolerance to FvTox1. H, Southern blot showing the HindIII fragments (shown by arrows) of $\mathrm{T}_{1}$ progenies that were associated with the expression of enhanced tolerance to FvTox1. 
ern blots were developed using the AP Conjugate Substrate Kit (Bio-Rad Laboratories).

\section{Plant expression vector construction.}

pISUAgron5 (modified pTF101.1, a derivative of pPZP binary vector) (Paz et al. 2004) was used to develop fusion genes for expression of anti-FvTox1 genes under the regulation of the Cauliflower mosaic virus $35 \mathrm{~S}$ promoter. Primers $(8-1 \mathrm{~F}$ and 4-2 R KDEL/6-1 R KDEL) (Table 1) were used to fuse the 4amino acid KDEL-tag in frame with the antibodies at their $\mathrm{C}$ termini. Binary vector plasmids were transformed into $\mathrm{A}$. rhizogenes K599 by a freeze-thaw method (Holsters et al. 1978).

\section{Transformation of soybean.}

Cotyledons of 7-day-old Williams 82 seedlings were harvested and surface sterilized with alcohol wipes (North Safety Products, Cranston, RI, U.S.A.) and infected with A. rhizogenes culture according to a previously published protocol (Subramanian et al. 2005). Stable transgenic soybean plants ( $\left.\mathrm{T}_{0}\right)$ were generated according to Paz and associates (2004). Seed of nontransgenic soybean plants were from those transformants $\left(\mathrm{T}_{0}\right)$ that did not show any BASTA resistance following transformation with the anti-FvToxl-1 transgene.

\section{Binding of anti-FvTox1 scFv antibodies expressed in transformed soybean roots.}

The transgenic roots generated 2 weeks following $A$. rhizogenes infection were harvested and frozen in liquid nitrogen and used for protein, DNA, and RNA isolation. For protein preparation, the tissue samples were extracted in phosphate buffer (5 mM EDTA, $100 \mathrm{mM}$ potassium phosphate, $1 \%$ Triton, $10 \%$ glycerol, and proteinase inhibitor cocktail at $1 \mu \mathrm{l} / \mathrm{ml}$ ) and centrifuged at $14,000 \times g$ and $4^{\circ} \mathrm{C}$. The supernatant was used as the crude antiFvTox 1 primary antibody. The mouse anti-KDEL monoclonal antibody (Stressgen, Ann Arbor, MI, U.S.A.) was used to detect the binding of the expressed antiFvTox $1 \mathrm{scFv}$ antibodies to FvTox1. The anti-KDEL antibody was detected with a goat anti-mouse secondary antibody conjugated to alkaline phosphatase (Bio-Rad Laboratories).

\section{RNA preparation and RT-PCR analyses of anti-FvTox 1 antibody genes,}

RNA was prepared using Trizol reagents (Invitrogen). RNA was treated with DNase (Invitrogen). The first-strand cDNAs were synthesized using Superscript II reverse transcriptase (Invitrogen). RT-PCR was conducted to determine expression levels of anti-FvToxl antibody genes (primers 8-1F and PolyATailR) (Table 1).

\section{Deletion analysis of FvTox1.}

The truncated versions of FvTox1 were created by PCR (forward primer FvTox $1 \mathrm{~F}$ and reverse primers R3, R4, R7, and FvTox1R) (Table 1) and cloned into the E. coli expression vector pRSET (Invitrogen). The truncated FvTox 1 proteins were expressed and separated in PAGE gels by following the protocol described for anti-FvTox $1 \mathrm{scFv}$ antibodies described earlier. For Western blot analyses, the anti-FvTox1 7E8 monoclonal antibody was diluted to 1:500 in 1× PBS.
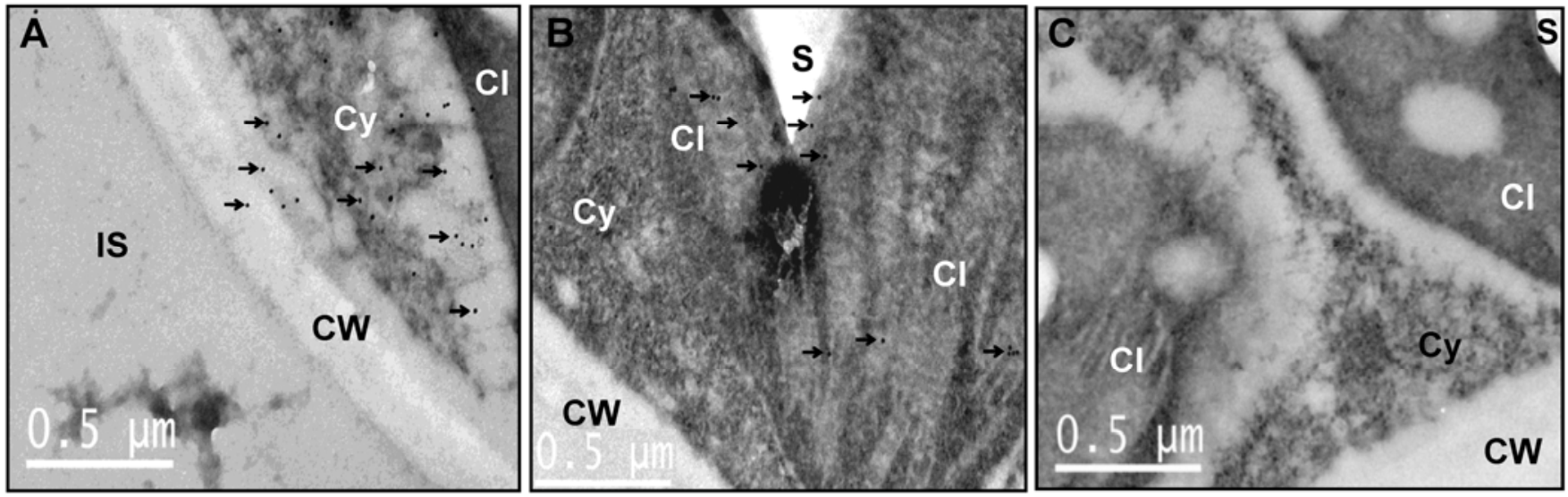

Fig. 5. Subcellular localization of anti-FvTox1-1 single-chain variable-fragment (scFv) antibody by transmission electron microscopy. Anti-FvTox1-1 was localized to cytoplasm and the chloroplasts (arrows) by anti-KDEL primary antibody and visualized with gold-labeled secondary antibody. A, Localization of anti-FvTox1 scFv antibody to cytoplasm (shown by arrows); $\mathbf{B}$, localization of anti-FvTox1 scFv antibody to chloroplasts (shown by arrows); and $\mathbf{C}$, leaf of a nontransgenic plant treated as in A and B. Electron micrographs presented here are representations of sections prepared from at least five leaves from each category. IS, intercellular space; CW, cell wall; Cy, cytoplasm; Cl, chloroplast; S, starch grain.

Table 1. List of primers used in this study

\begin{tabular}{ll}
\hline Primer & \multicolumn{1}{c}{ Sequence $\left(\mathbf{5}^{\prime} \mathbf{-} \mathbf{3}^{\prime}\right)$} \\
\hline Deg CH1 & GGGGCTAGC(T/C)CTCCACACACAGG(A/G)(A/G)CCAGTGGATAGAC \\
DegVH1 & GGGATATCCACCATG(G/A)A(G/C)TT(G/C)(T/G)GG(T/C)T(A/C)A(A/G)CT(G/T)G(G/A)TT \\
DegCk1 & GGGGTCGACACTGGATGGTGGGAAGATGGA \\
DegVk1 & GGGGATATCCACCATGGAGACAGACACACTCCTGCTAT \\
DegVk4 & GGGGATATCCACCATG(G/T)CCC(T/A)(G/A)CTCAG(T/C)T(T/C)CT(G/T)GT \\
8-1F & getggcggatcATGGGGATATCCACCATGAAGTTG \\
4-2 R KDEL & ggcagcgatcctagagctcatcttTTTCCAGCTTGGTCCCCCCCCGAAC \\
6-1 R KDEL & ggcagcggatcctagagctcatcttacgcAAGCTTggggtcgacactggatg \\
PolyATailR & CGAATGAGCTCCGGGAGGCCTAAGACGTGCTCAAATCAC \\
FvTox1F & CGACGGATCCGGCAGCGCAGCCAGATACGAGCCCATCGAC \\
R3 & GAGCGGATCCTTATGGATCGTACTCCTCAG \\
R4 & GAGCGGATCCTTACCAGTTTTCCTCACGGCAAAAG \\
R7 & GAGCGGATCCTTAGTCCTGGGCGCTGAGTGTTG \\
FvTox1R & GAGCGGATCCTTACTGTGGGTTGCGCACACAGTTG \\
\hline
\end{tabular}


Infection of soybean seedlings with $F$. virguliforme.

Soybean seed were grown in a 1:1 mixture of sand and soil containing $F$. virguliforme inocula grown on sorghum seed according to Mueller and associates (2002). Data were collected 5 weeks after inoculation. The plants were scored as follows: $0=$ no symptoms, $1=<10 \%$ chlorosis, $2=10$ to $20 \%$ chlorosis, $3=20$ to $50 \%$ chlorosis, $4=50$ to $80 \%$ chlorosis and necrosis, and $5=$ entire leaf chlorotic or necrotic.

\section{Stem-cut assay.}

Seeds of the Williams 82 plants that went through the transformation procedure but did not contain any transgenes and those of transgenic Williams 82 plants carrying the antiFvToxl-1 transgene were grown at $25^{\circ} \mathrm{C}$ for $16 \mathrm{~h}$ under light $(300 \mu \mathrm{E})$ and at $16^{\circ} \mathrm{C}$ for $8 \mathrm{~h}$ in darkness. Three-week-old seedlings were cut below the cotyledons and used for bioassays as according to a published protocol (Li et al. 1999). Symptoms started to appear 8 days following feeding of cellfree $F$. virguliforme culture filtrates. A published scoring scheme was used to measure the symptoms (Ji et al. 2006).

\section{Measurement of chlorophyll contents.}

Soybean leaf discs of approximately $1 \mathrm{~cm}^{2}$ in size were excised, placed in Eppendorf tubes, and frozen overnight at $-80^{\circ} \mathrm{C}$. Then, $1 \mathrm{ml}$ of $80 \%$ acetone was added to each tube and incubated at room temperature in darkness for 5 days. The acetone solution was measured for absorbency at 645 and $663 \mathrm{~nm}$. The amount of chlorophyll was calculated according to a published method (Arnon 1949).

\section{DNA preparation and Southern blot analysis.}

DNA was prepared using a modified cetyl-trimethyl ammonium bromide method (Cullings 1992) from $T_{1}$ progenies of a transformant. DNA of each transgenic plant $(10 \mu \mathrm{g})$ was digested with HindIII restriction endonuclease (New England Biolabs, Beverly, MA, U.S.A.) and separated on a $0.8 \%$ agarose gel, then transferred onto Zeta-Probe GT Nylon membrane (Bio-Rad Laboratories, Inc.), and DNA blot analysis was conducted according to a previously described protocol (Brar et al. 2011). A ${ }^{32} \mathrm{P}$-labeled probe was prepared using the $\mathrm{VH}$ chain 8-1 for hybridizing to the DNA blot.

\section{Microscopy.}

For transmission electron microscopy, tissues were sectioned and then fixed with $2 \%$ paraformaldehyde (wt/vol) and $0.1 \%$ glutaraldehyde (wt/vol) in $0.1 \mathrm{M}$ cacodylate buffer, $\mathrm{pH} 7.5$, for $2 \mathrm{~h}$ at $4{ }^{\circ} \mathrm{C}$, then rinsed with $\mathrm{dH}_{2} \mathrm{O}$. The samples were dehydrated in a graded ethanol series and infiltrated and embedded using LR White resin (Electron Microscopy Sciences, Ft. Washington, PA, U.S.A.). Resin blocks were polymerized for $48 \mathrm{~h}$ at $4{ }^{\circ} \mathrm{C}$ under UV light. Thick and ultrathin sections were prepared using a Reichert UC6 ultramicrotome (Leeds Precision Instruments, Minneapolis, MN, U.S.A.) and collected onto formvar-coated nickel grids. The grids were blocked for nonspecific binding using the incubation buffer (PBS with $2 \%$ bovine serum albumin and $0.01 \%$ fish gel) for $30 \mathrm{~min}$ at $22^{\circ} \mathrm{C}$. Grids were exposed to a 1:500 dilution of anti-KDEL antibody (Stressgen) for $3 \mathrm{~h}$ at $37^{\circ} \mathrm{C}$. The control grids were placed into fresh incubation buffer for $3 \mathrm{~h}$ at $37^{\circ} \mathrm{C}$. All grids were washed five times for $5 \mathrm{~min}$ each with incubation buffer and then exposed to a 1:30 dilution of $10 \mathrm{~nm}$ gold-conjugated goat antimouse immunoglobulin $\mathrm{G}$ secondary antibody for $2 \mathrm{~h}$ at room temp. Grids were washed with deionized water five times for 5 min at each step, then stained with $1 \%$ uranyl acetate in deionized water for no more than $5 \mathrm{~min}$. Grids were then stream washed with deionized water and dried prior to imaging. Images were captured using a JEOL 2100 scanning and transmis- sion electron microscope (Japan Electron Optic Laboratories, Peabody, MA, U.S.A.).

\section{ACKNOWLEDGMENTS}

We thank D. Luth (Plant Transformation Facility, Iowa State University) for generating the stable transgenic soybean plants; T. Pepper (Microscopy and Nanoimaging Facility, Iowa State University) for conducting microscopy experiments; and J. Baumbach, C. Brooke, H. Horner, and A. Miller (Iowa State University) and R. Shoemaker (United States Department of Agriculture-Agricultural Research Service) for critically reviewing the manuscript. This work was supported by a grant from the North Central Soybean Research Program.

\section{LITERATURE CITED}

Arnon, D. I. 1949. Copper enzymes in isolated chlorophlasts and polyphenol oxidase in Beta vulgaris. Plant Physiol. 24:1-15.

Better, M., Chang, C., Robinson, R., and Horwitz, A. 1988. Escherichia coli secretion of an active chimeric antibody fragment. Science 240:1041-1043.

Bird, R. E., Hardman, K. D., Jacobson, J. W., Johnson, S., Kaufman, B. M., Lee, S. M., Lee, T., Pope, S. H., Riordan, G. S., and Whitlow, M. 1988. Single-chain antigen-binding proteins. Science 242:423-426.

Bouaziz, D., Ayadi, M., Bidani, A., Rouis, S., Nouri-Ellouz, O., Jellouli, R., Drira, N., and Gargouri-Bouzid, R. 2009. A stable cytosolic expression of $\mathrm{VH}$ antibody fragment directed against PVY NIa protein in transgenic potato plant confers partial protection against the virus. Plant Sci. 176:489-496.

Brar, H. K., Swaminathan, S., and Bhattacharyya, M. K. 2011. The Fusarium virguliforme toxin FvTox1 causes foliar sudden death syndrome-like symptoms in soybean. Mol. Plant-Microbe Interact. 24:11791188

Capitani, M., and Sallese, M. 2009. The KDEL receptor: New functions for an old protein. FEBS (Fed. Eur. Biochem. Soc.) Lett. 583:38633871 .

Chaudhary, V. K., Batra, J. K., Gallo, M. G., Willingham, M. C., FitzGerald, D. J., and Pastan, I. 1990. A rapid method of cloning functional variableregion antibody genes in Escherichia coli as single-chain immunotoxins. Proc. Nat. Acad. Sci. U.S.A. 87:1066-1070.

Choi, G.-H., Lee, D.-H., Min, W.-K., Cho, Y.-J., Kweon, D.-H., Son, D.-H., Park, K., and Seo, J.-H. 2004. Cloning, expression, and characterization of single-chain variable fragment antibody against mycotoxin deoxynivalenol in recombinant Escherichia coli. Protein Express. Purif. 35:8492.

Cullings, K. W. 1992. Design and testing of a plant-specific PCR primer for ecological and evolutionary studies. Mol. Ecol. 1:233-240.

De Jaeger, G., Buys, E., Eeckhout, D., De Wilde, C., Jacobs, A., Kapila, J., Angenon, G., Van Montagu, M., Gerats, T., and Depicker, A. 1999. High level accumulation of single-chain variable fragments in the cytosol of transgenic Petunia hybrida. Eur. J. Biochem. 259:426-434.

De Neve, M., De Loose, M., Jacobs, A., Van Houdt, H., Kaluza, B., Weidle, U., and Van Montagu, M. 1993. Assembly of an antibody and its derived antibody fragment in Nicotiana and Arabidopsis. Transgenic Res. 2:227-237.

Eswarakumar, V. P., Raja, M. C., and Muthukkaruppan, V. R. 1997. RTPCR cloning and characterization of mouse immunoglobulin variable domains with high affinity for HLA-DR antigens. Immunogenetics 46:249-250.

Galeffi, P., Giunta, G., Guida, S., and Cantale, C. 2002. Engineering of a single chain variable fragment antibody specific for the Citrus tristeza virus and its expression in Escherichia coli and Nicotiana tabacum. Eur. J. Plant Pathol. 108:479-483.

Galeffi, P., Lombardi, A., Donato, M. D., Latinia, A., Sperandei, M. Cantale, C., and Giacomini, P. 2005. Expression of single-chain antibodies in transgenic plants. Vaccine 23:1823-1827.

Hiatt, A., Caffferkey, R., and Bowdish, K. 1989. Production of antibodies in transgenic plants. Nature 342:76-78.

Holsters, M., Waele, D. D., Depicker, A., Messens, E., Montagu, M. V., and Schell, J. 1978. Transfection and transformation of Agrobacterium tumefactions. Mol. Gen. Genet. 163:181-187.

Huston, J. S., Levinson, D., Mudgett-Hunter, M., Tai, M., Novotny, J., Margolies, M. N., Ridge, R. J., Bruccoleri, R. E., Haber, E., Crea, R., and Oppermann, H. 1988. Protein engineering of antibody binding site: Recovery of specific activity in an anti-digoxin single-chain Fv analogue produced in Escherichia coli. Proc. Natl. Acad. Sci. U.S.A. 85:5879-5883.

Ji, J., Scott, M. P., and Bhattacharyya, M. K. 2006. Light is essential for 
degradation of ribulose-1,5-bisphosphate carboxylase-oxygenase large subunit during sudden death syndrome development in soybean. Plant Biol. 8:597-605.

Jobling, S. A., Jarman, C., Teh, M.-M., Holmberg, N., Blake, C., and Verhoeyen, M. E. 2003. Immunomodulation of enzyme function in plants by single-domain antibody fragments. Nat. Biotechnol. 21:77-80.

Kabat, E. A., Wu, T. T., Perry, H. M., Gottesman, K. S., and Foeller, C., eds. 1991. Sequences of Proteins of Immunological Interest, 5th ed. NIH publication No. 91-3242. U.S. Department of Health and Human Services, U.S. Government Printing Office.Washington, DC.

Kazi, S., Shultz, J., Afzal, J., Johnson, J., Njiti, V., and Lightfoot, D. 2008. Separate loci underlie resistance to root infection and leaf scorch during soybean sudden death syndrome. Theor. Appl. Genet. 116:967-977.

Kleffmann, T., Russenberger, D., von Zychlinski, A., Christopher, W., Sjölander, K., Gruissem, W., and Baginsky, S. 2004. The Arabidopsis thaliana chloroplast proteome reveals pathway abundance and novel protein functions. Curr. Biol. 14:354-362.

Le Gall, F., Bove, J. M., and Garnier, M. 1998. Engineering of a singlechain variable-fragment ( $\mathrm{scFv}$ ) antibody specific for the stolbur phytoplasma (Mollicute) and its expression in Escherichia coli and tobacco plants. Appl. Environ. Microbiol. 64:4566-4572.

Li, H.-P., Zhang, J.-B., Shi, R.-P., Huang, T., Fischer, R., and Liao, Y.-C. 2008. Engineering Fusarium head blight resistance in wheat by expression of a fusion protein containing a Fusarium-specific antibody and an antifungal peptide. Mol. Plant-Microbe Interact. 21:1242-1248.

Li, S., Hartman, G. L., and Widholm, J. M. 1999. Viability staining of soybean suspension cultured cells and a stem-cutting assay to evaluate phytotoxicity of Fusarium solani f. sp. glycines culture filtrates. Plant Cell Rep. 18:375-380.

Mueller, D. S., Hartman, G. L., Nelson, R. L., and Pedersen, W. L. 2002. Evaluation of Glycine max germ plasm for resistance to Fusarium solani f. sp. glycines. Plant Dis. 86:741-746.

Paz, M. M., Shou, H., Guo, Z., Zhang, Z., Banerjee, A. K., and Wang, K. 2004. Assessment of conditions affecting Agrobacterium-mediated soybean transformation using the cotyledonary node explant. Euphytica 136:167-179.

Peschen, D., Li, H. P., Fischer, R., Kreuzaler, F., and Liao, Y. C. 2004. Fusion proteins comprising a Fusarium-specific antibody linked to antifungal peptides protect plants against a fungal pathogen. Nat. Biotechnol. 22:732-738.

Proba, K., Honegger, A., and Plückthun, A. 1997. A natural antibody missing a cysteine in $\mathrm{VH}$ : Consequences for thermodynamic stability and folding. J. Mol. Biol. 265:161-172.

Proba, K., Wörn, A., Honegger, A., and Plückthun, A. 1998. Antibody scFv fragments without disulfide bonds, made by molecular evolution. J.
Mol. Biol. 275:245-253.

Radhamony, R. N., and Theg, S. M. 2006. Evidence for an ER to Golgi to chloroplast protein transport pathway. Trends Cell Biol. 16:385-387.

Rajabi-Memari, H., Jalali-Javaran, M., Rasaee, M. J., Rahbarizadeh, F., Forouzandeh-Moghadam, M., and Esmaili, A. 2006. Expression and characterization of a recombinant single-domain monoclonal antibody against MUC1 mucin in tobacco plants. Hybridoma 25:209-215.

Rupe, J. C. 1989. Frequency and pathogenicity of Fusarium solani recovered from soybean with sudden death syndrome. Plant Dis. 73:581-584.

Safarnejad, M., Fischer, R., and Commandeur, U. 2009. Recombinantantibody-mediated resistance against Tomato yellow leaf curl virus in Nicotiana benthamiana. Arch. Virol. 154:457-467.

Schouten, A., Roosien, J., De Boer, J. M., Wilmink, A., Rosso, M. N., Bosch, D., Stiekema, W. J., Gommers, F. J., Bakker, J., and Schots, A. 1997. Improving $\mathrm{scFv}$ antibody expression levels in the plant cytosol. FEBS (Fed. Eur. Biochem. Soc.). Lett. 415:235-241.

Subramanian, S., Graham, M. Y., Yu, O., and Graham, T. L. 2005. RNA interference of soybean isoflavone synthase genes leads to silencing in tissues distal to the transformation site and to enhanced susceptibility to Phytophthora sojae. Plant Physiol. 137:1345-1353.

Sunderasan, E., Kadir, R. A., Pujade-Renaud, V., Lamotte, D. F., Yeang, H. Y., and Nathan, S. 2009. Single-chain variable fragments antibody specific to Corynespora cassiicola toxin, cassiicolin, reduces necrotic lesion formation in Hevea brasiliensis. J. Gen. Plant Pathol. 75:19-26.

Tavladoraki, P., Benvenuto, E., Trinca, S., De Martinis, D., Cattaneo, A., and Galeffi, P. 1993. Transgenic plants expressing a functional singlechain Fv antibody are specifically protected from virus attack. Nature 366:469-472.

Wrather, J. A., and Koenning, S. R. 2006. Estimates of disease effects on soybean yields in the United States 2003 to 2005. J. Nematol. 38:173180.

Xu, J. L., and Davis, M. M. 2000. Diversity in the CDR3 region of VH is sufficient for most antibody specificities. Immunity 13:37-45.

Yajima, W., Verma, S. S., Shah, S., Rahman, M. H., Liang, Y., and Kav, N. N. V. 2010. Expression of anti-sclerotinia scFv in transgenic Brassica napus enhances tolerance against stem rot. New Biotechnol. 27:816821.

Yuan, Q., Hu, W., Pestka, J. J., He, S. Y., and Hart, L. P. 2000. Expression of a functional antizearalenone single-chain FV antibody in transgenic Arabidopsis plants. Appl. Environ. Microbiol. 66:3499-3505.

\section{AUTHOR-RECOMMENDED INTERNET RESOURCE}

The Abysis database: www.bioinf.org.uk/abysis/index.html 